総 説

\title{
低酸素刺激による血管系の改築と疾患
}

\author{
池田栄二 \\ 山口大学医学部情報解析医学系·病理学第一講座 宇部市南小串 1 丁目 1 - 1 （テ755-8505）
}

Key words：低酸素，血管新生，血液網膜関門，糖尿病網膜症

\section{和文抄 録}

我々ヒトの生命活動は，主として酸素をエネルギ 一源とした細胞の代謝により維持されている。そし て，細胞・組織・生体は，周囲酸素濃度の低下に対 し様々な反応を示す。それらの反応は，低酸素環境 においても細胞・組織・生体が機能するための代償 性反応機構とみなされるが，ヒトの疾患においては 病態を悪化させる要因として働く場合が多い. 酸素 を末梢組織へ運ぶ通路である血管は，酸素濃度変化 に対し敏感に反応し，様々な改築を示し種々の疾患 の病態に深く関わることが知られている。我々は, 網膜血管の改築が本態である糖尿病網膜症の病態に ついて, 基礎生物学的ならびに臨床病理学的側面か ら解析を行ってきた，糖尿病網膜症では，病変部局 所の低酸素状態を誘因とした血管新生および網膜血 管バリアー機能破綻が生じる, 我々は, 組織低酸素 状態により誘発される血管新生が, vascular endothelial growth factor (VEGF) mRNAの安定 化抒よびhypoxia-inducible factor 1 (HIF-1) pathwayの活性化を介したVEGF遺伝子の転写充進 に担われることを明らかにした。そして，臨床病理 検体の解析を通じ, 糖尿病網膜症の網膜血管新生病 変形成には, 低酸素状態にある病変部局所のグリア 細胞に産生が誘導されるVEGF，特にアイソフォー ム VEFE165 と, 細胞外マトリックス分解酵素matrix metalloproteinase 2 (MMP-2) の活性化因子である membrane-type1 matrix metalloproteinase (MT1-

平成 21 年 6 月 25 日受理
MMP）が主役を演ずることが示唆された．一方， 網膜血管バリアー機能の破綻については, 血管内皮 細胞間tight junctionの構成分子であるclaudin-5に 焦点を当てた解析を行い，これまでに低酸素刺激に よるclaudin-5発現変化が主因であることを示す知見 を得ている. 本稿では, これまでの我々の研究成果に ついて, 文献的考察をまじえて概説する。

\section{はじめに}

ヒトは，肺から取り込まれた酸素をエネルギー源 として利用し生命活動を維持している。 十分な酸素 供給が得られず低酸素状態に陥った組織は正常な機 能を営むことが困難となり, 高度の低酸素状態は組 織の壞死さらには生体の死へとつながる. 低酸素刺 激が加わった急性期には, 生体は呼吸容量を増して より多くの酸素を生体内に取り入れるとともに, 細 胞の代謝を好気性から嫌気性に変化させる（図 1 )。 そして, 低酸素状態が持続すると, 未梢組織への酸 素運搬効率を上げるため, 赤血球の産生立進, 局所 組織への血管新生が惹起される（図 1)。これらは, 細胞・組織・生体が低酸素環境下においても生存す るために獲得した代償性反応機構ととらえられる が，種々の疾患においては病態を悪化させる要因と して働くという一面も有している。

我々は，低酸素刺激に対する細胞・組織反応を， 特に血管系の改築を中心に, 疾患の病態との関連に おいて解析を進めてきた。本稿では，これまで我々 が行ってきた研究につき, 文献的考察をまじえて概 説する. 


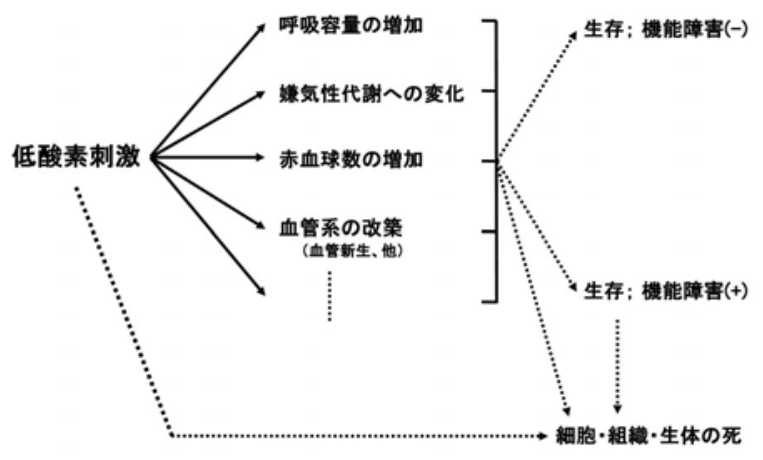

図 1

低酸素刺激に対する細胞・組織・生体の反応，酸素濃 度の低下した環境において生存するため, 細胞・組織・ 生体は様々な反応を示す。低酸素刺激に反応した血管系 の改築は，種々の疾患においては病態悪化に働くという 一面を有している。

\section{1．低酸素誘発性血管新生のメカニズム解析}

成人の血管系は比較的静的な状態にあるが，固形 腫瘍などの病的状態においては，病変部局所におけ る組織低酸素状態に反応した血管新生が惹起され る。これまで，血管新生を促進あるいは抑制する活 性を示す多くの制御因子が特定・単離されたが，局 所組織における血管の増生状態は，それら血管新生 促進因子と血管新生抑制因子の活性のバランスに依 存する。いわゆる血管新生病と称される固形腫瘍, 関節リウマチ，糖尿病網膜症などの病態について， 臨床検体を用いた多くの解析結果が報告され，病変 部の血管新生は，主として，血管新生因子vascular endothelial growth factor (VEGF) の活性に依存す ることが明らかにされた。ささにそれれらの疾患に おけるVEGF産生立進には, 病変部局所組織の低酸 素状態が重要な誘因として働いていることが示され た ${ }^{1)}$. そこで, 我々は, 低酸素誘発性血管新生のメ力 ニズムを明らかにすべく，低酸素刺激によるVEGF 産生克進過程に焦点を絞った解析を開始した。

ラット・グリオーマ細胞株を低酸素濃度下（1％ 酸素）に培養すると, VEGFタンパク質の産生立進 が認められ，この低酸素刺激によるVEGF産生艺進 が，VEGF遺伝子の転写立進とVEGF mRNAの安 定化の両方に担われていることを見出した（図 2 A).さらに, VEGF遺伝子の5’ 領域の解析を通じ, 低酸素刺激に反応してVEGF遺伝子の転写を充進さ せるエンハンサー配列を特定した ${ }^{2)}$.そのエンハン

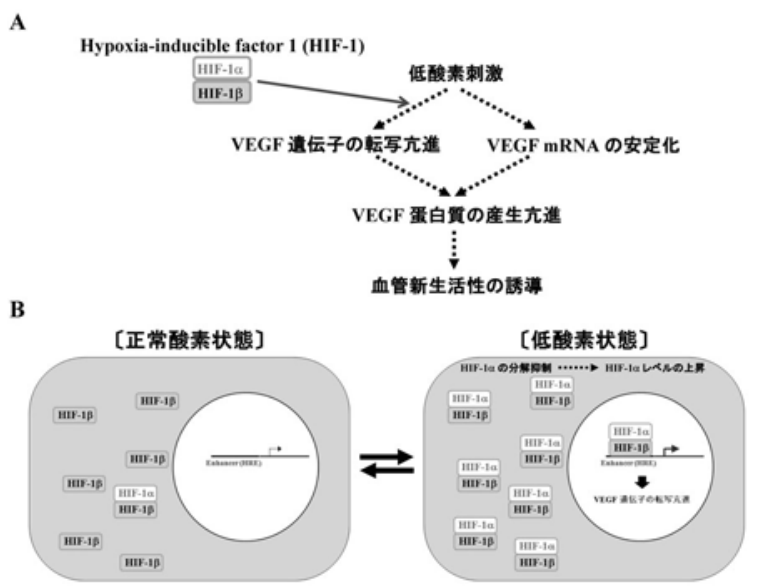

図 2 低酸素誘発性血管新生のメカニズム

（A）低酸素刺激下にある細胞では，VEGF遺伝子の転写 立進とVEGF mRNAの安定化を介してVEGF蛋白質 の産生が立進することにより血管新生活性が誘導さ れる。低酸素刺激によるVEGF遺伝子の転写立進は, 転写因子hypoxia-inducible factor 1（HIF-1）の制御 下にある.HIF-1は，HIF-1 $\alpha$ と HIF-1 $\beta$ のへテロダ イマーからなる。

（B）正常酸素濃度下にある細胞ではHIF-1 $\alpha$ は速やかに分 解されるため, HIF-1 $\alpha$ 蛋白質レベルは低い。一方, 低酸素濃度下の細胞ではHIF-1 $\alpha$ の分解抑制により HIF-1 $\alpha$ 蛋白質が上昇し, HIF-1 $\beta$ とダイマーを形成 し，VEGF遺伝子のエンハンサー領域へ結合する。 その結果, VEGF遺伝子の転写艺進が起こり，血管 新生活性が誘導される。

サー領域に結合する因子がhypoxia-inducible factor 1 （HIF-1）とAP1であること，低酸素刺激による VEGF遺伝子の転写㐫進には，エンハンサー領域へ のHIF-1の結合が必須であることを明らかにした (図 $2 \mathrm{~A}, \mathrm{~B})^{3}$.

低酸素環境下に生活する生体では赤血球の産生が 立進していることが知られている，HIF-1は，低酸 素刺激に反応し erythropoietin（EPO）遺伝子の転 写を光進させる活性を持った転写因子として特定さ れた ${ }^{4)}$. HIF-1は, HIF-1 $\alpha$ とHIF-1 $\beta$ からなるへテ ロダイマーを形成する. HIF-1 $\beta$ タンパク質レベル は酸素濃度に依存せず一定であるが, HIF-1 $\alpha$ 夕ン パク質レベルは酸素濃度依存性に変化する。低酸素 状態下では，HIF-1 $\alpha$ タンパク質の分解が抑制され ることにより HIF-1 $\alpha$ タンパク質レベルが上昇し， HIF-1 $\alpha$ とHIF-1 $\beta$ からなるダイマーが形成される とともに, HIF-1 $\alpha$ タンパク質と転写補助因子との 結合も促進され，転写因子HIF-1としての活性が誘 導される (図 2 B)。HIF-1は, EPO, VEGF産生の 他にも多くの分子の産生を制御していることが報告 
され，低酸素刺激に対する細胞反応の中枢に位置す る重要なpathwayを形成していることが明らかにさ れた1)。

\section{2．糖尿病網膜症における血管系改築}

我々は，基礎生物学的解析と並行し，種々の疾患 の病態解析について，臨床病理組織検体を用いた解 析を進めた。本稿では，糖尿病網膜症についての病 態解析成果を紹介する。

糖尿病網膜症は，先進国における成人の中途失明 原因の上位に位置する疾患であり，網膜血管の改築 が病態の中枢となっている。初期には網膜血管バリ アー機能（血液網膜関門機能）の破綻，そして病期 が進むと網膜血管新生を併発する，特に後者は，網 膜から硝子体に及ぶ血管新生病変である線維血管性 組織を形成することにより，率引性網膜剥離の原因 となり視力予後を規定する.

まず，糖尿病網膜症患者から手術的に切除された 線維血管性組織について, HIF-1 $\alpha$ タンパク質の発 現を解析したところ，病変部においてHIF-1 $\alpha$ タン パク質の発現立進所見が認められた。組織低酸素状 態が網膜血管病変形成の誘因として重要な役割を担 っていることを示す知見と考え，組織低酸素状態と いう側面から糖尿病網膜症の病態解析を進めてき た，以下に，線維血管性組織形成および網膜血管バ リアー機能破綻のメカニズムについて，これまでの 我々の研究成果を紹介する.

\section{1 ) 網膜血管新生病変 (線維血管性組織) 形成のメ カニズム}

線維血管性組織は，網膜から硝子体に及ぶ血管新 生により形成される。従って，病変形成には，局所 における血管新生活性とともに，網膜前基底膜組織 に対する蛋白分解活性の誘導が必須であり, 我々は, 両者の活性誘導機構について解析を進めた。血管新 生活性の誘導については，HIF-1 pathwayにより発 現が制御される血管新生因子VEGFの関与に焦点を あて解析を進めた。VEGF遺伝子は 8 個のexonから なり, alternative splicingにより生化学的・生物学 的特性の異なる複数のisoformが生成されることが 報告されている，我々は，手術的に採取された線維 血管性組織検体の解析を行い, 血管新生病変として
の線維血管性組織の活動性が，グリア細胞における isoform VEGF 165 の産生と相関することを見出した5). 網膜前基底膜組織に対する蛋白分解活性について は, 種々の生理学的・病理学的組織改築において中 心的役割を演ずる蛋白分解醳素familyである matrix metalloproteinase (MMP) familyに注目し解析を 進めた。硝子体内における蛋白質レベルを測定した ところ, 線維血管性組織の形成を伴った糖尿病網膜 症症例においてMMP-2とMMP-9の蛋白質レベルが 有意に上昇していることが判明した，MMPの活性 は，蛋白質のレベルとともに活性化の有無に依存す るため，硝子体内および線維血管性組織における MMP-2 とMMP-9の活性化状態につき検索を加え た。その結果，硝子体および線維血管性組織ともに MMP-2の活性化率が高く, 特に線維血管性組織に おけるMMP-2の活性化が顕著であることが示され た。すなわち，MMP-2が線維血管性組織形成に働 く蛋白分解活性の責任因子であることが強く示唆さ れた、MMP-2は潜在型として産生され，膜型MMP の一つである membrane-type 1 matrix metalloproteinase（MT1-MMP）により活性型 MMP-2へと変換される。このMMP-2活性化過程で は「潜在型MMP-2/MT1-MMP/TIMP-2」からなる 複合体形成が必須であるが，これらの因子が線維血 管性組織に存在するグリア細胞に共存しており，糖 尿病網膜症の病変形成部位では，グリア細胞におけ るMMP-2活性化機構が充進していることを示す知 見と考えられた。病変形成部位局所において活性化 されたMMP-2が，網膜前基底膜の分解を介して線 維血管性組織形成に働いていることが示唆された6).

続いて，線維血管性組織形成における「組織低酸 素状態 $\rightarrow$ HIF-1 pathway活性化」というカスケー ドの重要性を検証すべく, 網膜グリア細胞の単離・ 培養系を確立し解析を進めた，培養グリア細胞に低 酸素刺激を加えると，VEGF 165 の発現とともに MT1-MMPの発現が立進することが示された. MMP-2には有意な発現誘導は認められなかった。 即ち, 線維血管性組織形成の責任因子として我々が 特定した血管新生因子VEGF 165 の産生と, 蛋白分解 酵素MMP-2の活性化因子MT1-MMPの産生が，低 酸素状態にある網膜グリア細胞において誘導される ことが明らかになった。さらに，低酸素刺激による MT1-MMP産生誘導が，VEGFを介した間接的な機 
構によることも見出した，即ち，「組織低酸素状態 $\rightarrow$ HIF-1 pathway活性化 $\rightarrow \mathrm{VEGF}_{165}$ 産生立進 $\rightarrow$ MT1-MMP産生光進 $(\rightarrow$ MMP-2活性化 $\rightarrow$ 線維血 管性組織形成 $\rightarrow$ 視力障害)」という機構が, 糖尿 病網膜症の病態悪化の一端を担うという興味梁い知 見が得られた（図 3 ) 7。

\section{2 ) 網膜血管バリアー機能破綻のメカニズム}

網膜には血液網膜関門が存在し, 網膜組織の微小 環境を至適状態に維持している。血液網膜関門は, 色素上皮細胞の形成するバリアーと網膜血管内皮細 胞の形成するバリアーとからなり，後者は血液脳関 門の本態である血管バリアーと同質と考えられてい る。糖尿病網膜症では, 病初期より網膜血管バリア 一機能の破綻が起こり視力障害の原因となることが 知られているが, その誘因としては, 種々のサイト カイン・糖化蛋白質 (advanced glycation endproduct, AGE) などとともに, 組織低酸素状 態が挙げられている。これまで我々は，低酸素状態 にある脳や網膜などの神経系組織において，血管バ リアー機能が障害される機構につき解析を進めた。

血管バリアー機能は, 主として内皮細胞間に形成 されるtight junction網に担われている. Tight junction構成分子としてoccludin, claudin, junctional adhesion moleculeなどが特定・単離され ているが，なかでも 24 種類の分子からなる claudin

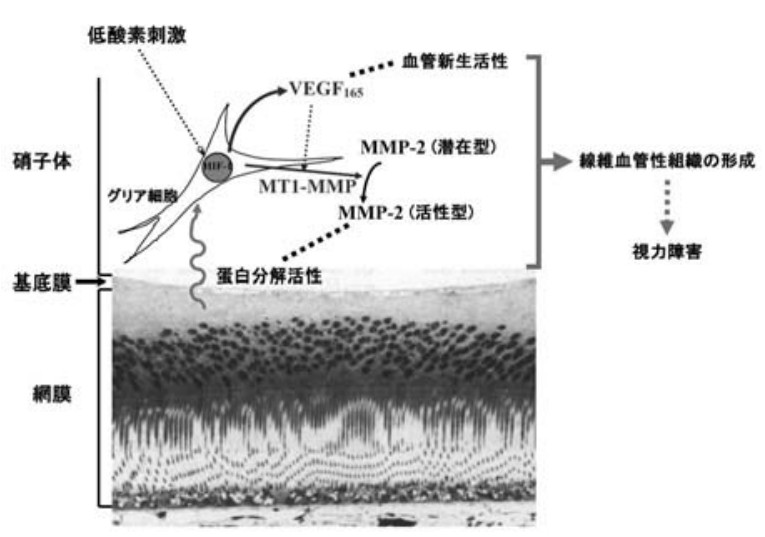

図 3

糖尿病網膜症における網膜血管新生病変（線維血管性 組織）形成のメカニズム。網膜グリア細胞が，周囲組織 の低酸素状態に反応してVEGF165の産生が立進することに より血管新生活性が誘導される。さらに, VEGF 165 が MMP-2活性化酵素であるMT1-MMPの産生を惹起し, 病 変部局所に蛋白分解活性が誘導される。 その結果, 網膜 から硝子体に及ぶ血管新生病変が形成される. familyがtight junctionの構築と機能に重要な役割を 果たしている。神経系組織の毛細血管内皮細胞では claudin-1, claudin-3, claudin-5, claudin-12の発現 が報告されているが，ノックアウトマウスの解析か らは，血管バリアー機能に扔ける claudin-5の関与が 注目されている ${ }^{8}$. そこで我々は, in vitroおよびin $v i v o$ 低酸素実験系を確立し, 低酸素刺激による血管 バリアー機能の破縃機構について, claudin-5の発現 動態に焦点を絞った解析を行った。In vitro低酸素 実験系としては，マウス脳血管由来の内皮細胞株 bEND.3を用いた。 Confluent状態のbEND.3細胞を 正常酸素濃度下に培養すると, 細胞膜に限局した claudin-5の発現が認められた。一方, 低酸素濃度下 では，bEND.3細胞における claudin-5発現レベルが 低下するとともに, 細胞膜へのclaudin-5分子の局在 が抑制されることを見出した。ささら，バリアー機 能の指標としてbEND.3 細胞層の電気抵抗值 (transendothelial electrical resistance; TEER) を 測定したところ, claudin-5の発現・局在変化に依存 してTEERが低下することが示された。正常酸素濃 度下あるいは低酸素濃度下（ $7-9 \%$ 酸素濃度, 7 日間）に飼育したマウスの網膜組織を用いたin vivo低酸素実験系においても, 正常酸素代謝状態に あるマウスの網膜組織では血管内皮細胞の細胞膜に 局在したclaudin-5の発現がみられるのに対し，低酸 素代謝状態に陥った網膜組織では, 血管内皮細胞に
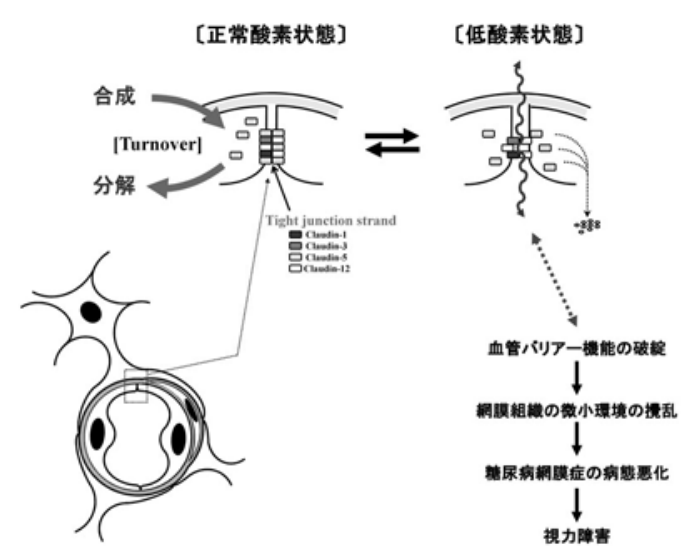

图 4

糖尿病網膜症における網膜血管バリアー機能破綻のメ カニズム。神経系組織の血管内皮細胞間に形成される tight junctionの構成分子として, claudin-1, claudin-3, claudin-5, claudin-12が報告されている。糖尿病網膜症の 病変部では, 低酸素状態にある血管内皮細胞において claudin-5の細胞膜への局在が低下し血管バリアー機能が 障害される。 
おける細胞膜へのclaudin-5の局在が低下していた. そして，低酸素代謝状態では，血管透過性，特に低 分子量分子に対する透過性が選択的に立進している ことが示された。この低分子量分子に対する透過性 立進は, claudin-5ノックアウトマウスの神経系血管 の形質と同質であり，低酸素状態下での血管バリア 一機能破綻の責任因子としてのclaudin-5の重要性を 示す所見と考えられる。すなわち，糖尿病網膜症の 病態における「組織低酸素状態 $\rightarrow$ 血管内皮細胞に おけるclaudin-5の発現変化 $\rightarrow$ 血管バリアー機能の 破綻 $\rightarrow$ 網膜組織の微小環境の攪乱 $\rightarrow$ 病態悪化」 という機構の重要性を示す興味深い知見が得られた (図 4$)^{9)}$. 今後, claudin-5をターゲットとした新た な治療法開発の可能性が期待される.

\section{おわりに}

低酸素組織に起こる血管系の改築について，血管 新生と神経系血管バリアー機能の破綻を中心に概説 した。基礎生物学的解析成果とともに，血管系の改 築という側面から進めてきた疾患病態解析成果につ いて，糖尿病網膜症を例にあげて紹介した。

\section{参考文献}

1) Ikeda E. Cellular response to tissue hypoxia and its involvement in disease progression. Pathol Int 2005 ; 55 : 603-610.

2 ) Ikeda E, Achen MG, Breier G, Risau W. Hypoxia-induced transcriptional activation and increased mRNA stability of vascular endothelial growth factor in $\mathrm{C} 6$ glioma cells. J Biol Chem 1995 ; 270 : 19761-19766.

3 ) Damert A, Ikeda E, Risau W. Activatorprotein-1 binding potentiates the hypoxiainducible factor-1-mediated hypoxia-induced transcriptional activation of vascularendothelial growth factor expression in C6 glioma cells. Biochem J 1997 ; 327 : 419-423.
4) Semenza GL, Wang GL. A nuclear factor induced by hypoxia via de novo protein synthesis binds to the human erythropoietin gene enhancer at a site required for transcriptional activation. Mol Cell Biol 1992 ; 12 : 5447-5454.

5 ) Ishida S, Shinoda K, Kawashima S, Oguchi Y, Okada Y, Ikeda E. Co-expression of VEGF receptors VEGF-R2 and neuropilin-1 in proliferative diabetic retinopathy. Invest Ophthalmol Vis Sci $2000 ; 41: 1649-1656$.

6 ) Noda K, Ishida S, Inoue M, Obata K, Oguchi Y, Okada Y, Ikeda E. Production and activation of matrix metalloproteinase- 2 in proliferative diabetic retinopathy. Invest Ophthalmol Vis Sci $2003 ; 44: 2163-2170$.

7 ) Noda K, Ishida S, Shinoda H, Koto T, Aoki T, Tsubota K, Oguchi Y, Okada Y, Ikeda E. Hypoxia induces the expression of membranetype 1 matrix metalloproteinase in retinal glial cells. Invest Ophthalmol Vis Sci 2005; 46 : 3817-3824.

8 ) Nitta T, Hata M, Gotoh S, Seo Y, Sasaki H, Hashimoto N, Furuse M, Tsukita S. Sizeselective loosening of the blood-brain barrier in claudin-5-deficient mice. J Cell Biol 2003 ; $161: 653-660$.

9 ) Koto T, Takubo K, Ishida S, Shinoda H, Inoue M, Tsubota K, Okada Y, Ikeda E. Hypoxia disrupts the barrier function of neural blood vessels through changes in the expression of claudin-5 in endothelial cells. Am J Pathol $2007 ; 170$ : 1389-1397. 


\title{
Hypoxia-induced Remodeling of Vasculature and Its Involvement in Disease Progression
}

\author{
Eiji IKEDA
}

Department of Pathology I. and Radiological and Pathological Sciences, Yamaguchi University School of Medicine, 1-1-1 Minami Kogushi, Ube, Yamaguchi 755-8505, Japan

\section{SUMMARY}

Human cells utilize oxygen as the source of energy, and show various reactions when they are exposed to the environment with decreased oxygen concentration. These reactions enable the cells to survive under hypoxic conditions, whereas they often accelerate the progression of diseases such as diabetic retinopathy. Vasculature, the pathways for oxygen delivery to peripheral tissues, is sensitive to the changes in surrounding oxygen concentration, and the remodeling of retinal vasculature by hypoxia is known to determine the progression of diabetic retinopathy. Vascular remodeling in diabetic retina includes the angiogenesis and the breakdown of blood-retinal barrier function. Our studies have indicated that the hypoxic induction of vascular endothelial growth factor (VEGF), especially its isoform VEGF 165 , and membrane-type 1 matrix metalloproteinase (MT1-MMP) in retinal glial cells is responsible for the formation of angiogenic lesion in diabetic retinopathy. On the other hand, the breakdown of barrier function of diabetic retinal vessels is attributable to the hypoxiainduced changes in the expression of a tight junction protein, claudin-5, in endothelial cells. In this review, I summarize the data of our studies on the mechanisms underlying the hypoxic remodeling of vasculature and its involvement in disease progression of diabetic retinopathy. 